\title{
Jolanta Migdał
}

\author{
Instytut Filologii Polskiej \\ Uniwersytet im. Adama Mickiewicza w Poznaniu
}

DOI: 10.14746/psj.2014.XXVII.7

\section{Określenia beneficjentów Kościoła katolickiego w szesnastowiecznej polszczyźnie}

Religia i Kościół towarzyszą dziejom Polski od jej początków. „Jako instytucja, Kościół przejawia się w sposób niezwykle zróżnicowany. Posiada określoną strukturę i bogatą tradycję, przejawem jego instytucjonalności jest podział na parafie i diecezje, cała różnorodność zakonów i duszpasterstwa specjalistycznego, kościoły i rozmaite gmachy kościelne, instytucje charytatywne, uczelnie i wydawnictwa. Ale na instytucjonalność Kościoła składa się również liturgia i teologia, prawo kanoniczne i zwyczaje lokalne, sztuka kościelna i tradycje językowe" chia kościelna, dostojnicy Kościoła, pełniący różnorakie funkcje i piastujący różne godności. Są to również beneficjenci, czyli osoby, którym przysługują kościelne beneficja i związane z tym dochody.

Według opracowań leksykograficznych, zarówno tych ogólnych, jak i tych specjalistycznych, beneficjum to „2. religijny, historyczny $<\mathrm{w}$ Kościele rzymskokatolickim: urząd, z którym związane są dochody > ", „, w dawnej Polsce dobra kościelne, stanowiące źródło dochodów księży kanoników"3. Jak wynika $\mathrm{z}$ tych definicji lub z towarzyszących im kwalifikatorów, beneficjum wiązane jest głównie z przeszłością Kościoła. Przyjrzyjmy się więc, w jaki sposób

${ }^{1}$ J. Salij, Kościót jako instytucja, w: idem, Pytania nieobojętne, Poznań 1997, zob. www. mateusz.pl lub www.nonpossumus.pl (dostęp: 15.05.2014).

${ }^{2}$ Praktyczny słownik wspótczesnej polszczyzny, red. H. Zgółkowa, t. 4, Poznań 1995, s. 43; dalej skrót PSWP. Podobną definicję zamieszcza Uniwersalny słownik języka polskiego: „2. rel. 'w Kościele katolickim: stanowisko, urząd, z którym związane są dochody'; Uniwersalny stownik języka polskiego, red. S. Dubisz, t. 1, Warszawa 2003, s. 219; dalej skrót USJP.

${ }^{3}$ Religia. Encyklopedia PWN, red. T. Gadacz, B. Milerski, t. 1, Warszawa 2001, s. 22. 
nazywano w XVI wieku osoby obdarzone urzędami, z którymi wiązały się określone dochody.

Podstawą źródłową moich rozważań jest Słownik polszczyzny XVI wieku ${ }^{4}$. Uważam bowiem, że stanowi on najlepsze pod względem kompletności dzieło do badań ówczesnego słownictwa. Zdaję sobie oczywiście sprawę, że w szesnastym stuleciu nastąpił szybki rozwój wszelakiego piśmiennictwa i literatury. Wielką rolę w tym przyspieszeniu odegrał druk i możliwość powielania tekstów w wielu egzemplarzach ${ }^{5}$. Mam więc świadomość, że ze względu na te czynniki, w celu stworzenia słownika ówczesnej leksyki - Słownika polszczyzny XVI wieku, niemożliwa była ekscerpcja wszystkich szesnastowiecznych tekstów (co możliwe było w odniesieniu do Słownika staropolskiego). Powstał jednak odpowiednio skonstruowany kanon źródeł. Redakcja SPXVI określa go w następujący sposób: ,podstawą materiałową Słownika jest zbiór tekstów XVI-wiecznych, reprezentujących możliwie wszystkie formy piśmiennicze: wierszowane i prozatorskie, ciągłe i dialogowane, retoryczne, naukowe, narracyjne itp. o różnej genezie społecznej i różnym stopniu literackości, pochodzących ze wszystkich dzielnic ówczesnej Polski"6. Na tej podstawie można więc przyjąć, że słownik ten odnotowuje całość ówczesnego słownictwa z różnych dziedzin ${ }^{7}$. Chcę też w tym miejscu zaznaczyć, że korzystam wyłącznie z opublikowanych dotychczas tomów słownika ${ }^{8}$.

SPXVI odnotował 10 określeń odnoszących się do osób, którym przysługiwały różnorakie kościelne beneficja i związane z tym dochody.

Najbardziej ogólnymi tego typu nazwami w XVI wieku były beneficjat i prebendarz.

Pierwsza z nich - beneficjat oznaczająca duchownego w Kościele katolickim posiadającego urząd kościelny, z którym są złączone dochody z dóbr ko-

${ }^{4}$ Stownik polszczyzny XVI wieku, t. I-XXXV, red. M.R. Mayenowa, F. Pepłowski, K. Mrowcewicz, Wrocław-Warszawa-Kraków 1966, Warszawa 2011. W dalszej części artykułu na oznaczenie tego słownika stosuję skrót SPXVI.

${ }_{5}^{5}$ I. Bajerowa, Wpływ techniki na ewolucje języka polskiego, Kraków 1980.

${ }^{6}$ Zob. www.ibl.waw.pl (dostęp: 15.05.2014).

${ }^{7}$ Oczywiście autorzy SPXVI zdają sobie sprawę ,jak dalece ten [zebrany] materiał jest daleki od ideału kompletności”(SPXVI, t. I, s. IX). Jednak, aby uzyskać jak najpełniejszy obraz ówczesnej leksyki, autorzy uzupełniają materiał o ,hasła nie występujące w [...] kartotece, a znalezione przygodnie $\mathrm{w}$ innych tekstach szesnastowiecznych lub w partiach pominiętych przy niepełnej ekscerpcji” (SPXVI, t. I, s. XXVI).

${ }^{8}$ Czyli do hasła rowny. Bardzo trudne, jeśli nie niemożliwe są bowiem badania pozostałego materiału zgromadzonego w Pracowni SPXVI. Indeksy haseł oraz kartoteka nie są jeszcze wyposażone w znaczenia, aby więc znaleźć ewentualne nazwy beneficjentów z nieopracowanych liter alfabetu, trzeba by przeczytać wszystkie cytaty i na ich podstawie określić znaczenia. Praca ta przekracza możliwości jednej osoby. 
ścielnych ${ }^{9}$ - wystąpiła $\mathrm{w}$ tekstach czterokrotnie ${ }^{10}$. To określenie zastosowali: Marcin Bielski w Kronice w 1564 roku, Piotr Skarga w Żywotach świętych w 1579 roku oraz Stanisław Sarnicki (dwukrotnie) w Statutach i metryce przywilejow koronnych w 1594 roku. Marcina Bielskiego można uznać za tego, który po raz pierwszy (na co wskazują źródła SPXVI) tej nazwy w polszczyźnie użył11. Nie była ona bowiem znana w poprzednich wiekach, o czy świadczy brak takiego hasła w Stowniku staropolskim ${ }^{12}$ (przypomnę, że SStp powstał w wyniku całkowitej ekscerpcji wszystkich tekstów powstałych do końca XV stulecia). O tym, że rzeczownik beneficjat wszedł do polszczyzny w XVI wieku jako pożyczka łacińskiego beneficiatus, po odrzuceniu końcówki -us pisze Danuta Moszyńska $^{13}$. Można przyjać, że forma ta nie była też kontynuowana w kolejnym wieku ${ }^{14}$. Ciekawe jest natomiast to, że współcześnie, jako jeden $\mathrm{z}$ wariantów określenia, znana jest polszczyźnie kościelnej. Powstająca w Lublinie Encyklopedia Katolicka notuje bowiem hasło beneficjat, beneficjant, beneficjariusz, odnosząc je do „osoby duchownej, która mocą prowizji kanoniczej otrzymała beneficjum" ${ }^{15}$. Z artykułu dowiadujemy się także, że „uprawnienia i obowiązki beneficjata ustala KPK w kanonach 1472-1483" oraz — co może zastanawiać w świetle danych SStp — że „termin powstał na przełomie XIII i XIV wieku” Warto też zauważyć, że współcześnie w polszczyźnie ogólnej funkcjonują dwie inne formy beneficjant i beneficjent ${ }^{17}$. Zmianę pierwotnej postaci tak thumaczy Maciej Malinowski: „Za „poprawniejszy” i gramatycznie uzasadniony trzeba niewątpliwie uznać ten pierwszy (o zakończeniu -ant), ponieważ właśnie przyrostkiem -ant tworzono od wieków w polszczyźnie rzeczowniki pochodzenia łacińskiego odpowiadające imiesłowom czynnym. Skoro zatem chodziło o osobę czerpiącą zyski z jakichś dóbr, nazwano ją beneficj-antem.

Gwoli ścisłości powiem, że początkowo posługiwano się formą o wygłosie -at, a nie: -ant, czyli mówiono i pisano beneficjat, np. Nie wymagano obecności

9 Podając znaczenia poszczególnych leksemów, stosuję parafrazy definicji sformułowanych przez autorów SPXVI.

${ }^{10}$ SPXVI, t. II, s. 44.

${ }^{11}$ Można przypuszczać, że beneficjat funkcjonował w polszczyźnie przed wydaniem dzieła Marcina Bielskiego, ale póki ta hipoteza nie znajdzie potwierdzenia w tekstach, należy pierwszeństwo zapisu oddać właśnie temu twórcy.

${ }_{12}$ Zob. Słownik staropolski, red. S. Urbańczyk, Kraków 1953-2002, t. I-XI. W dalszej części stosuję skrót SStp.

${ }_{13}$ D. Moszyńska, Morfologia zapożyczeń łacińskich i greckich w staropolszczyźnie, Wrocław-Warszawa-Kraków-Gdańsk 1975, s. 81.

${ }^{14}$ Nie zawiera takiego hasła (także w postaci beneficjant, beneficjent) indeks Stownika języka polskiego XVII i 1. połowy XVIII wieku; dalej stosuję skrót SJPXVII.

${ }^{15}$ Encyklopedia Katolicka, t. II, Lublin 1976, s. 262.

${ }^{16}$ Ibidem.

17 Zob. PSWP, t. 4, 1995, s. 43; USJP, t. 1, s. 219; Stownik 100 tysięcy potrzebnych słów, red. J. Bralczyk, Warszawa 2005, s. 48; dalej stosuję skrót BR. 
beneficjata; Beneficjat z kościoła św. Jana; Każdorazowo beneficjat byt innej narodowości. Wyszła ona jednak z użycia być może dlatego, że stała się z czasem synonimem słowa beneficjum, a niewykluczone, iż również dlatego, że doszukano się w niej... uchybienia słowotwórczego. Otóż zakończenie -at nosiły spolonizowane latynizmy wtedy, gdy chodziło o ich funkcję imiesłowową bierną, np. delegat ('ktoś wybrany') z łac. delegatus, purpurat (dosłownie 'odziany w purpurę') z łac. purpuratus czy sensat ('człowiek uczony, mądry') z łac. sensatus. W myśl tego nie powinna się więc pojawić w obiegu forma beneficjat, tylko beneficjant, bo rzecz dotyczyła 'człowieka korzystającego z czegoś' (korzystajacy to imiesłów przymiotnikowy czynny).

Jeszcze bardziej obrazuje ową kwestię taki oto przykład. W dawnej polszczyźnie istniały wyrazy adresat ('odbiorca listu, przesyłki') oraz adresant ('ktoś, kto wysyła list, przesyłkę'). Pierwszy pozostał do dziś, drugi wyszedł z użycia, zastąpiony przez nadawce, ale był (i jest) jak najbardziej poprawny. Tak samo trzeba zapamiętać, że nominat 'osoba nominowana' to nie to samo co nominant 'osoba nominująca kogoś'"'18.

Drugie interesujące mnie, występujące w szesnastowiecznej polszczyźnie określenie to prebendarz ${ }^{19}$. Odnosiło się ono do duchownego obdarzonego prebendą, czyli uposażeniem w ziemi, rodzajem beneficjum zapewniającym utrzymanie. Zwykle powiązane było z funkcją kanonika. Nazwa ta zastosowana została co najmniej (przykłady pochodzą też z nieobjętych statystyką źródeł spoza kanonu SPXVI) pięciokrotnie. Użyte zostało przez Marcina Bielskiego w Kronice z 1564 roku (3 razy) i Stanisława Sarnickiego w Statutach i metryce przywilejow koronnych z 1594 roku (2 razy). Wyekscerpowane zostało także z tekstów spoza kanonu źródeł: u Jana Seklucjana w Studencie w 1549 roku oraz w Poborze pogłównym na sejmie walnym koronnym warszawskim roku 1590 uchwalonym. Na ogólne oznaczenie korzystającego z prebendy po raz pierwszy i jedyny w XV wieku zastosowano nazwę prebendzarz w krakowskich księgach sądowych w $1445 \mathrm{roku}^{20}$. Nazwa ta stanowi zapożyczenie z łacińskiej formy prebendarius, w której wycofano oryginalny formant -arius i zastąpiono rodzimym - $a r z^{21}$. Prebendarz był także kontynuowany w polszczyźnie w kolejnych stuleciach $^{22}$. Współcześnie nie używa się już określenia, chociaż jako odnoszące się do historiii ${ }^{23}$ jest ono nadal znane w języku kościelnym. Encyklopedia Katolicka informuje, że prebendarzem była „osoba posiadająca prebendę w kapitule kate-

18 M. Malinowski, Obcy język polski (236): Jak beneficjant stat się beneficjentem [http://obcyjezykpolski.strefa.pl/?md=archive\&id=235 (dostęp: 15.05 .2014$)]$.

${ }^{19}$ SPXVI, t. XXX, s. 243.

${ }^{20}$ SStp, t. VII, s. 50. Zob. też: D. Moszyńska, op. cit., s. 25.

${ }^{21}$ D. Moszyńska, op. cit., s. 42-43.

${ }^{22}$ Hasło prebendarz znajduje się w indeksie SJPXVII.

${ }^{23}$ Autorzy Encyklopedii Katolickiej informują, że system prebend funkcjonował w Kościele katolickim do XIX wieku. Zob. Encyklopedia Katolicka, op. cit., t. XVI, 2012, s. 338. 
dralnej lub kolegiackiej i korzystająca z jej dochodów; niekiedy także [był to] ten, kto miał prawo do udziału w obradach kapituły i miejsca w chórze"24.

Kolejne szesnastowieczne określenia osób korzystających z beneficjów to mansyjonaryjus, mensyjonarysta i mensyjonarz. Pierwszą z tych nazw - mansyjonaryjus — odnotowano w XVI wieku tylko jeden raz u Marcina Krowickiego w Obronie nauki w roku 1560. Znaczenie jej zdefiniowane jest jako 'mansjonarz, tytuł, jaki posiadają niektórzy kapłani będący wikariuszami przy kościele katedralnym lub kolegiackim, rzadziej przy kościele parafialnym lub filialnym'25. Można by więc zastanawiać się, czy rzeczywiście oznacza ona kościelnego beneficjenta, osobę czerpiącą zyski z beneficjum. Autorzy SPXVI uzupełniają jednak to hasło synonimami mensyjonarysta i mensyjonarz. A definicje tych haseł nie budzą już żadnych wątpliwości, jednoznacznie wskazując na beneficjenta. I mensyjonarysta i mensyjonarz oznaczają bowiem 'duchownego utrzymywanego z dochodów beneficjum i obowiązanego w zamian za to do spełniania określonych obowiązków kościelnych' ${ }^{26}$. Mensyjonarysta jest — podobnie jak mansyjonaryjus — hapaks legomenon z tekstu Marcina Krowickiego Obrona nauki. Częściej stosowano w XVI wieku formę mensyjonarz, która mogła też wystąpić $\mathrm{W}$ wariantywnej postaci mansjonarz. Zapisana została pięciokrotnie przez Marcina Krowickiego w Obronie nauki w roku 1560, Marcina Bielskiego w Kronice z 1564 roku (dwukrotnie) i Stanisława Sarnickiego w Statutach i metryce przywilejow koronnych z 1594 roku (dwukrotnie). Poświadczona jest także w tekstach spoza kanonu źródeł SPXVI: w Rozmowie nowej niektórego Pielgrzyma z Gospodarzem o niektórych cerymoniach kościelnych Stanisława ze Szczodrkowic Morawickiego w 1549 roku, w Lustracji województwa mazowieckiego z 1565 roku oraz w Lustracji województwa plockiego z lat 1565-1789. Wszystkie wymienione w tej grupie formy są charakterystyczne dla XVI stulecia, nie zapisano ich w średniowieczu, ale także nie były kontynuowane w kolejnych wiekach. Według Danuty Moszyńskiej wszystkie formy mansyjonaryjus, mansjonarz, mensyjonarz wywodzą się z łacińskiego mansionarius ${ }^{27}$. Współcześnie natomiast znana jest $\mathrm{w}$ języku kościelnym nazwa mansjonarz, która nawiązuje do szesnastowiecznego znaczenia 'duchowny będący wikariuszem przy kościele katedralnym lub kolegialnym'28. Według Encyklopedii Katolickiej mansjonarzem nazywano beneficjata w rzymskich kapitułach zobowiązanego do zajęć w chórze, a także kościelnego ${ }^{29}$. Autorzy wspomnianego kompendium piszą też, że: „chrześcijanie określali tak stróżów kościelnych, którzy w Watykanie

${ }^{24}$ Ibidem.

${ }^{25}$ SPXVI, t. XIII, s. 147.

${ }^{26}$ Ibidem, s. 277.

27 D. Moszyńska, op. cit., s. 43-44.

${ }^{28}$ USJP, t. 2, s. 559; BR, s. 382; zob. też PSWP, w którym poświadczony jest również wariant mansjonariusz, PSWP, t. 20, 1999, s. 230.

${ }^{29}$ Encyklopedia Katolicka, op. cit., t. XI, 2006, s. 1181. 
m.in. pilnowali relikwii, dbali o oświetlenie kościoła, nosili krzyż na procesjach, odbierali ofiary; mansjonarzami były osoby duchowne i świeckie, [a] mansjonarze duchowni wspomagali kanoników kapituły np. w codziennym śpiewaniu oficjum o NMP; ich utrzymanie pozostawało w gestii prebendarza" ${ }^{30}$.

Dwa kolejne określenia kościelnych beneficjentów oznaczają administratorów beneficjum kościelnego. Są to komendarz i komendor. Komendarz wyekscerpowany został wyłącznie z tekstów spoza kanonu źródeł SPXVI. Jako nazwa tymczasowego administratora kościelnego beneficjum znalazł się $\mathrm{w}$ słowniku Cervusa z Tucholi z 1540 roku oraz w Inwentarzach mieszczańskich z lat 15281635 z ksiag miejskich Poznania ${ }^{31}$. Druga nazwa - komendor - zapisana została trzykrotnie w Liber Maleficorum, w Acta primi regiminis Sigismundi III z 1588 roku oraz w Statutach i metryce przywilejow koronnych w 1594 roku Stanisława Sarnickiego ${ }^{32}$. Chociaż oba te określenia mają poświadczenia średniowieczne, stanowią szesnastowieczną innowację. W poprzednich stuleciach występowały bowiem w wariantach komendor, komendar, komender w innym znaczeniu. Stosowane były jako tytuł w zakonie joannitów ${ }^{33}$. Pośrednio potwierdza taką opinię także Franciszek Sławski, który podaje, że hasło komentarz w znaczeniu 'administrator parafii, wikariusz' w polszczyźnie funkcjonuje od XVI wieku i pochodzi ,z śrłac. commendarius 'tymczasowy administrator beneficjum kościelnego"'34. Andrzej Bańkowski komendora odnosi tylko do komtura, a w źródłach wielkopolskich zwłaszcza do komtura joannickiego ${ }^{35}$. We współczesnej polszczyźnie, ani ogólnej, ani specjalistycznej, nie zachowały się omawiane określenia. Natomiast występuje obecnie w języku kościelnym forma komendatariusz 'osoba duchowna lub świecka (z dyspensą od obowiązku podjęcia życia zakonnego), której władza kościelna (także Stolica Apostolska) lub w porozumieniu z nią władza świecka ze względu na szczególne zasługi przekazywała w zarząd opactwo lub inny klasztor (komenda), początkowo dla zabezpieczenia interesów klasztoru, później również środków do życia prałatom pozbawionym siedzib wskutek inwazji ${ }^{36}$.

Kolejna nazwa kościelnego beneficjenta kortyzan, która pojawiła się dopiero w XVI wieku ${ }^{37}$, oznaczała duchownego ubiegającego się u papieża o beneficjum

${ }^{30}$ Ibidem.

31 SPXVI, t. X, s. 495.

32 Ibidem, s. 496.

${ }^{33}$ SStp, t. III, s. 321. Na ten temat piszę w artykule Nazwy zakonnych przełożonych $w$ szesnastowiecznej polszczyźnie [w druku].

${ }^{34}$ F. Sławski, Słownik etymologiczny języka polskiego, t. II, Kraków 1952-1982, s. 380. Według Andrzeja Bańkowskiego komentarz pochodzi z włoskiego commendatario 'zarządca prebendy kościelnej' (idem, Stownik etymologiczny języka polskiego, t. I, Warszawa 2000, s. 766).

${ }^{35}$ A. Bańkowski, loc. cit. O pochodzeniu nazwy komendor, ale w innym znaczeniu pisze też D. Moszyńska, op. cit., s. 75.

${ }^{36}$ Encyklopedia Katolicka, op. cit., t. IX, 2002, s. 440.

${ }^{37}$ Por. F. Sławski, op. cit., s. 500. 
z pominięciem polskiej władzy świeckiej lub duchownego posiadającego beneficjum w Polsce, a mieszkającego w Rzymie ${ }^{38}$. Poświadczona została w szesnastowiecznej literaturze aż 22 razy: w Zapiskach i rotach [...] z ksiag sqdowych ziemi warszawskiej z 1545 roku (3 razy), u Marcina Krowickiego w Obronie nauki w roku 1560 (2 razy), u Jana Palczowskiego w Ustawach prawa polskiego w 1561 roku, u Marcina Czechowica w Epistomium w 1583 roku oraz u Stanisława Sarnickiego w Statutach i metryce przywilejow koronnych w 1594 roku (15 razy). Ten ostatni autor obok formy kortyzan (czterokrotnie) zastosowal także wariant fonetyczny kortezan. I właśnie ta postać stała się formą kontynuowaną w kolejnych stuleciach ${ }^{39}$. Także i współcześnie znana jest $\mathrm{w}$ takiej postaci jako leksem religijny, historyczny, dawny ${ }^{40}$.

Dwa ostatnie, występujące w szesnastowiecznych tekstach, odnoszące się do osoby czerpiącej dochody z kościelnych beneficjów leksemy to altarysta i oltarzysta. Oba pojawiły się w polszczyźnie w tym stuleciu, nie poświadczono ich w piśmiennictwie średniowiecznym. Oznaczały duchownego pełniącego obowiązki przy określonym ołtarzu i posiadającego związane z tym dochody. Pierwsze z tych określeń wyekscerpowano dwukrotnie: z Obrony nauki z roku 1560 Marcina Krowickiego oraz ze Statutów i metryki przywilejow koronnych z 1594 roku Stanisława Sarnickiego ${ }^{41}$. Określenie to przetrwało do dzisiaj w dwóch wariantywnych formach, tej szesnastowiecznej, nawiązującej do łacińskiej podstawy altaria — altarysta — oraz w postaci bardziej spolszczonej altarzysta ${ }^{42}$.

Z kolei utworzony od rodzimego rzeczownika ottarz - ottarzysta - stanowi osobliwość zapisaną w Lustracji województwa krakowskiego z 1564 roku $^{43}$. Nazwa ta jawi się jako szesnastowieczne hapaks legomenon, ponieważ nie ma kontynuacji w późniejszej polszczyźnie.

Na zakończenie warto jeszcze raz podkreślić, że większość poświadczonych w szesnastowiecznej polszczyźnie nazw kościelnych beneficjentów pojawiła się właśnie w tym stuleciu. I ciekawe wydaje się także to, że mimo zaniku oznaczanych przez te nazwy urzędów i stanowisk, leksemy te w większości przetrwały do dzisiaj, jeśli nie w ogólnej polszczyźnie, to w jej kościelnej odmianie, choćby jako leksemy dawne czy historyczne. Świadczyć to może o sile tradycji polskiej nomenklatury kościelnej.

38 SPXVI, t. X, s. 658.

${ }^{39}$ Hasło znajduje się w indeksie SJPXVII. Franciszek Sławski informuje, że w kolejnym stuleciu pojawiła się także forma kortezjan, a w kolejnym wieku również nowe znaczenie 'dworzanin, dworak, pochlebca'. Por. idem, loc. cit.

${ }^{40}$ Zob. PSWP, t. 17, 1998, s. 346; BR, s. 322. Warto zauważyć, że w słowniku pod redakcją Jerzego Bralczyka pojawia się również wariant kortezanin.

${ }^{41}$ SPXVI, t. I, s. 146.

${ }^{42}$ BR, s. 13; Encyklopedia Katolicka, op. cit., t. I, 1973, s. 389.

${ }^{43}$ SPXVI, t. XXI, s. 332. 


\section{LITERATURA}

Bajerowa I., Wpływ techniki na ewolucję języka polskiego, Kraków 1980.

Bańkowski A., Słownik etymologiczny języka polskiego, t. I-II, Warszawa 2000.

Encyklopedia Katolicka, t. I-XIX, Lublin 1973-2014.

Malinowski M., Obcy język polski (236): Jak beneficjant stat się beneficjentem, w: http:// obcyjezykpolski.strefa.pl/?md=archive\&id=235.

Moszyńska D., Morfologia zapożyczeń łacińskich i greckich w staropolszczyźnie, Wrocław-Warszawa-Kraków-Gdańsk 1975.

Praktyczny słownik współczesnej polszczyzny, red. H. Zgółkowa, t. 1-50, Poznań 1994-2005.

Religia. Encyklopedia PWN, red. T. Gadacz, B. Milerski, t. 1-9, Warszawa 2001-2009.

Salij J., Kościół jako instytucja, w: J. Salij, Pytania nieobojętne, Poznań 1997, w: www.mateusz.pl lub www.nonpossumus.pl.

Sławski F., Słownik etymologiczny języka polskiego, t. I-V, Kraków 1952-1982.

Słownik języka polskiego XVII i 1. połowy XVIII wieku - www.sxvii.pl.

Stownik polszczyzny XVI wieku, t. I-XXXV, red. M.R. Mayenowa, F. Pepłowski, K. Mrowcewicz, Wrocław-Warszawa-Kraków 1966 - Warszawa 2011.

Stownik staropolski, red. S. Urbańczyk, t. I-XI, Kraków 1953-2002.

Słownik 100 tysięcy potrzebnych słów, red. J. Bralczyk, Warszawa 2005.

Uniwersalny słownik języka polskiego, red. S. Dubisz, t. 1-4, Warszawa 2003.

www.ibl.waw.pl, tu: spxvi.edu.pl.

\section{Jolanta Migdał}

\section{Designations of the Beneficiaries of the Catholic Church in the 16th-Century Polish}

The article discusses ten 16th-century designations of the beneficiaries of the Catholic Church, that is the persons endowed with offices, which were connected with specific profits. These names have been excerpted from the published volumes of Słownik polszczyzny XVI wieku ("The Dictionary of the 16th-Century Polish"). The article presents their origin and subsequent history. It is worth noting that the majority of the names of church beneficiaries that were confirmed in the 16th-century Polish language appeared just in that century. Despite the disappearance of offices and posts designated by them, the greater part of those lexemes have survived until today, if not in general Polish, than in its ecclesiastical variety as obsolete or historical lexemes.

Keywords: 16th-century Polish, religious lexis, church beneficiaries 